\title{
Galvanometer design
}

\section{Silas W. Holman}

To cite this article: Silas W. Holman (1897) Galvanometer design, Philosophical Magazine Series 5, 43:263, 315-316, DOI: 10.1080/14786449708620997

To link to this article: http://dx.doi.org/10.1080/14786449708620997

$$
\text { 曲 Published online: } 08 \text { May } 2009 .
$$

Submit your article to this journal 전

LII Article views: 2

Q View related articles ¿ 
2. The Boulder Beds are next described, their distribution noted, and their occurrence with aolian deposits recorded. The author argues that the rolian deposits once had a greater slope, and acted as carriers, so that, under the influence of rain, the stones from the hills slipped to their present position.

3. The Quartzite Reefs are described as filling up cracks; the material is of æolian origin and derived from the surrounding rocks, and owing to this material having been formerly at a lower level than the latter, water stood on it for a sufficiently long time to permit of the materials being cemented by a siliceous deposit, and converted into quartzite.

4. The Infratrappean Grits are maintained to be superficial deposits on the pre-trappean land-surface, some being the ordinary results of weathering, others due to the washing down of débris to a watercovered level, and others again simply wolian drift. It is thus seen that there has been constancy in the meteorologieal conditions of Cutch from recent times as far back as the Cretaceuus period.

5 . The Laterite-deposits of the district, occur to a beight of only 120 feet above the Rănn. There is evidence that they were laid down in water at a time when the surface of the country was not very different from the present one. The material may have been partly derived from Jurassic rocks, but some of the constituents, as the eroded agates, must have come from the trap-rocks.

6. The kănn is an area which has recently been abandoned by the sea, owing to unequal movements, but there is evidence that deposit has also taken place in it, and the depression has become shallower, so that in course of time the whole surface will be made of alluvial or æolian soil.

\section{Intelligence and Miscellaneous Articles.}

GALVANOMETER DESIGN.

\section{To the Editors of the Philosophical Magazine.}

\section{Gentlemen,}

DERMIT me to acknowledge the courtesy and entire correctI ness of Professor Gray's recent Jetter (Phil. Mag. January 1897) respecting my note on Galvanometer Design (Phil. Mag. December 1895). Professor Gray perfectly apprehends my point of view in the matter, and very clearly indicates the nature of the omission which constitutes my error. That this was its nature 1 had already discovered in reflecting upon the note by Professors Ayrton and Mather (Phil. Mag. November 1896). It had been my intention to briefly point out the fact as soon as some additional experimental data could be obtained. But as this would probably cause some further delay, owing to my inability to participate in active work, I take the opportunity afforded by Professor Gray's remarks to recognize the correctness of the 
demonstration by Messrs. Ayrton, Mather, and Sumpner in their original paper. It may be well, however, to note that this conclusion does not vitiate the inferences which were the main point of my former paper, namely, the comparative inefficiency of the central portion of the coil, even if wound in reverse order, and the consequent importance of employing exceedingly short needles.

Boston, Mass., February 18, 1897.

Simas W. Holman.

ON MAQNETIC AFTER-ACTION. BY PROF. IGN. KLEMENC,TC.

The magnetic induction which is observed in soft iron wires which have been annealed for some time, and are placed in weak fields, is made up of two parts; a fact established by Ewing (Phil. Trans. 1885, p. 569, and Proc. Roy. Soc. 1889) and Lord Rayleigh (Phil. Mag. 1887). One part follows the production or cessation of magnetizing force; the second part begins after the termination of the former, and develops itself very slowly, so that the intensity of magnetization attains its final value only after some minutes. The phenomenon of a time retardation was denoted as "creeping" or viscous hysteresis; it is here called " magnetic after-action." It is very probable that the establishment of magnetic after-action in the middle of the wire proceeds more rapidly than at the ends.

Magnetic after-action occurs mostly in weak fields; it diminishes with the strength of the field, and the more rapidly the thinner the wire under investigation.

No regular connexion between the magnetic after-action and the thickness of the wire could be made out, probably owing to unequal annealing.

Strong magnetizations of the wires in no wise affect their magnetic after-action.

Magnetic after-action is a transitory phenomenon, which is only observed in freshly-annealed bars.- Wiener Berichte, March 1897.

\section{MAGNGTIC INFLUENCE ON LIGHT-FREQUENCY.}

The footnote on page 232 (March no.) was by the communicator, not the author, of the paper ; and he notes that the simplest way of putting the elementary theory, for an ion or electron revolving in an orbit of fixed size but any shape, is to write the radial magnetic force as

whence

$$
\begin{gathered}
d\left(m r \omega^{2}\right)=e \mathrm{~B} \omega, \\
2 \pi n=d \omega=e \mathrm{~B} / 2 m,
\end{gathered}
$$

$n$ being the magnetically-caused change of frequency, and $B$ the density of magnetic induction, or $\mu \mathrm{H}$.-EDs. 